\title{
TO DEVELOP THE ACCEPTABLY MODERN. SLOVENIAN URBAN LANDSCAPE UNDER SOCIALISM, 1969-1982 ${ }^{1}$
}

VERONICA E. APLENC

The creation of an intrusive neighborhood development plan by state officials is not surprising for a socialist society. In the case of Trnovo, the state's initial 1969 development plan met with tremendous opposition, but after some giveand-take among professionals over the next 10 years was implemented in slightly modified form. Official urban planners, professionally prominent individuals, and Trnovo locals each defined themselves - and their version of Trnovo - as modern, but in mutually incompatible ways. The urban landscape that emerged was a physically diverse one, with old farmhouses competing with an expanding socialist suburbia, and this reflected competing beliefs about Trnovo, Ljubljana, and modernity.

Key words: Trnovo, Ljubljana, modernity, late 20th century, urban development, modern city residents.
Nasilni urbanistični načrti za stanovanjske soseske, ki so bili plod državnih uradnikov, za socialistično družbo niso nič presenetljivega. V primeru Trnovega je prvotni urbanistični načrt iz leta 1969, ki ga je izdelala državna uprava, trčil na silovit odpor. Po desetletju izmenjave mnenj in kompromisov med strokovnjaki je bila na podlagi rablo spremenjenega načrta soseska končno dograjena leta 1982. Uradni urbanisti, posamični ugledni strokovnjaki in pa prebivalci Trnovega so sebe in svojo podobo Trnovega imeli za sodobne, uskladiti troje različnih pogledov pa je bilo nemogoče. Urbana krajina, ki se je na koncu rodila, je bila fizicno zelo raznolika: stare kmetije so tekmovale $z$ rastocim socialisticnim predmestjem, celotna podoba pa je odsevala različne poglede na Trnovo, Ljubljano in pojmovanje sodobnosti.

Ključne besede: Trnovo, Ljubljana, modernost, pozno 20. stoletje, urbani razvoj, moderni mestni prebivalci.

\section{INTRODUCTION}

Professional ethnologist and Trnovo local Mojca Otorepec Tercelj opens her 2001 monograph Trnovski tičarji in solatarce (Trnovo Poultry Breeders and Lettuce-Ladies) thus:

Do we notice people that still today head out every day to the market, the same as people used to do eighty years ago? These are the people from Trnovo that have a long tradition, that have been linked to Ljubljana throughout history through the way they supplied food. [Otorepec Tercelj 2001: 9-10] $]^{2}$

Otorepec Tercelj is describing her home neighborhood in Ljubljana, Slovenia. The Trnovo neighborhood had long enjoyed a "folksy" reputation as the city's historic gardening district located just outside the old medieval city center. Between the 17th and early 19 th centuries,

1 A talk given by Veronica E. Aplenc at the American Association for the Advancement of Slavic Studies (AAASS) National Convention, held in Boston, Massachusetts, USA, 4-7 December 2004.

2 All translations of Slovenian material are the author's. 


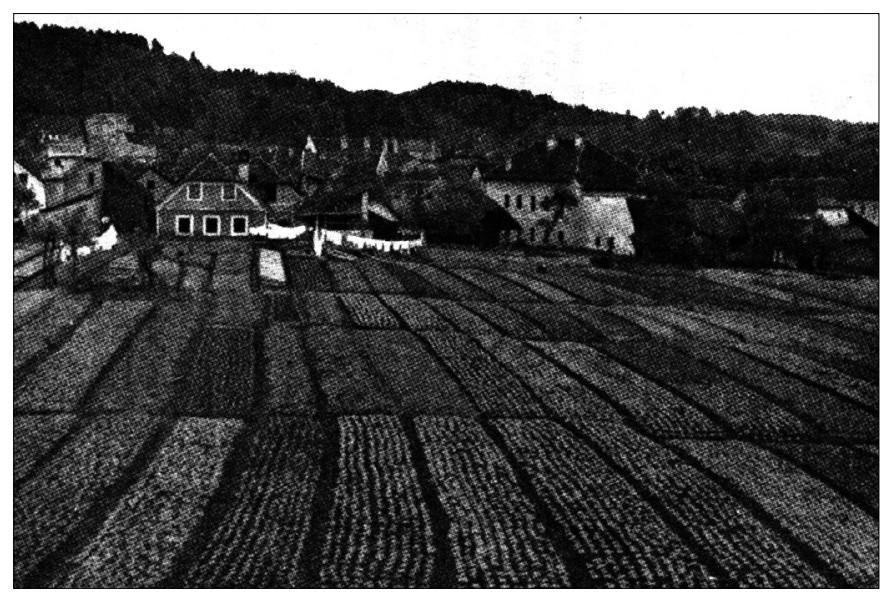

Figure 1: Historic Krakovo gardens [Vrhovnik 1933].

Trnovo developed into a commercially vibrant extension of Ljubljana that provided key services to the town, including commercial gardening. Although Trnovo was incorporated into greater Ljubljana in the mid-1800s, it retained its outlying-village atmosphere, even after internationally acclaimed Slovenian architect Jože Plečnik designed riverfronts and bridges for the neighborhood in the 1930s.

Otorepec Tercelj continues:

Until the 1970s, Trnovo was a village section of Ljubljana. The main traffic vein, Karunova Ulica, was still graveled. How it rattled when the "lettuce-ladies" set off with their pushcarts to the market! Small and large houses still stood, and so did the gardens. In the 1980s it happened. Suddenly houses were knocked down, and the feverish construction of new housing developments began. People moved away, some built new houses for themselves in Trnovska Gmajna [the Trnovo commons], and others went to different parts of Ljubljana. Some found themselves in temporary housing, and then they moved into the new - modern apartments with balconies [upscale] or without [less upscale]. For many old Trnovo residents, Trnovo no longer exists. In its place stands an urbanized settlement. [Otorepec Tercelj 2001: 14-15]

In this passage, Tercelj Otorepec refers to the enormous physical, and related social, changes that took place in Trnovo in the 1980s, when high-rise housing was built in the area. From 1969 to 1982, state-appointed urban planners created a housing plan for the Trnovo neighborhood in Ljubljana, then part of Yugoslavia, which called for the demolition of historic housing in favor of high-rises and socialist suburbia. The creation of an intrusive neighborhood development plan by state officials is not surprising for a socialist society. In the case of Trnovo, the initial plan of 1969 met with tremendous opposition, and through some give-and-take among professionals over the next 10 years was slightly toned down, but built by 1982 . The urban landscape that emerged was a physically diverse one, with 
old farmhouses interspersed among high-rises and an expanding socialist suburbia, and this physical landscape reflected a landscape of competing beliefs about Trnovo and about modernity. Official urban planners, professionally prominent individuals, and Trnovo locals each defined themselves - and their version of Trnovo - as modern, but grounded their visions in incompatible definitions of the Other.

\section{THE DEVELOPMENT PLAN}

The eradication of Trnovo clearly suggests an official desire to erase an undesirable element and reconstitute it appropriately into socialist ways of being. The first series of plans for Trnovo, begun 1969 and adopted in 1972, echoed contemporary trends in planning that focused on creating new urban environments for the full development of the socialist citizen. In particular, the plan for Trnovo aligns with the declared Yugoslav planning vision of erasing the differences between urban and rural communities [Mihelič 1983]. That Trnovo was chosen for this is not surprising, because it figured as a very well-known, rural-like community within Ljubljana, and ethnographies of 1689 (Valvasor) and 1933 (Vrhovnik) have dealt with its "folk."

As planning historian Breda Mihelič and fellow scholars have detailed [Mihelič 1983; Mlinar 1978], by the early 1960s the push for modernization in postwar Yugoslavia had come to include the erasure of differences between rural and urban communities. In addition, by the early 1960s a new planning profession had emerged and dedicated itself to establishing guides for social and economic growth. A key concept that urban planners debated in the theorizing of the 1960s was the modern neighborhood (Sln. soseska) and its most appropriate forms [Mušič 1980; Pogačnik 1984]. Sociologists, for their part, argued that within such neighborhoods each individual would be able to realize his or her full potential [Mlinar 1983]. In written discussions among urban planners of this period, the "modern" neighborhood always took the form of architecturally "modern," high density, multistoried buildings, which were grouped around services deemed "necessary" such as grocery stores, bars, and small shops. As is to be expected, none of these discussions note an engagement with the built remnants of the past; rather, the first comprehensive plan for all of Ljubljana,

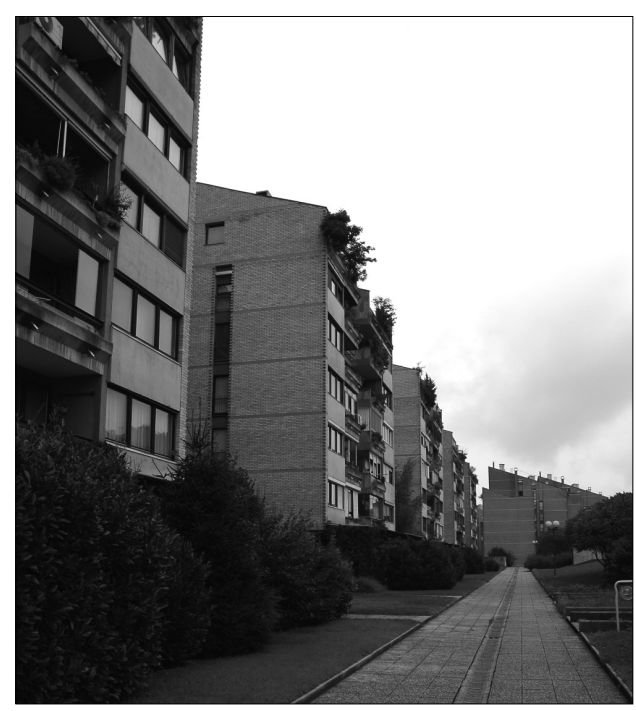

Figure 2: Trnovo high-rises [Photo: J. Fikfak, 2005]. 


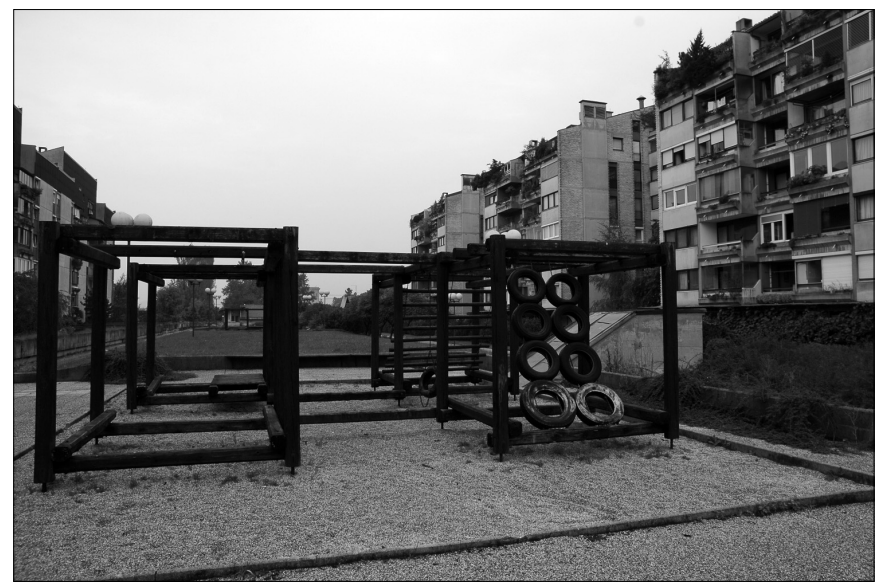

Figure 3: Trnovo high-rises

[Photo: J. Fikfak, 2005].

the 1966 Generalni urbanistični plan Ljubljane (General Urban Plan for Ljubljana), deals with historic preservation issues by detailing an intricate plan of monuments to the People's Revolution (Ljudska revolucija) [LUZ 1966].

This state-created socialist vision of modernity within urban planning is clearly reflected in the first series of plans for Trnovo, produced from 1969 to 1972. State-educated urban planners of the Ljubljana Urban Planning Institute (Ljubljanski urbanistični zavod, LUZ) issued documents from 1969 to 1972 that outlined their vision of the new Trnovo. Of these, the 1970 Technical Section of the Construction Plan and the 1972 Program Section of the Construction Plan have been preserved in archives. These documents focus on all aspects of the plan, including architectural analysis, economic analysis, and proposals for new housing, social service centers, green spaces, and municipal services. In particular, they spell out the construction of a new Trnovo neighborhood with groups of high-rises that surround social services, such as schools, small shops, the equivalent of a community center that could seat 200, snack bari 'bars', and similar establishments [LUZ 1970: 5-10] aimed to promote social life. According to these initial documents, essentially all of "old" Trnovo would be demolished to make way for high-rise construction and the expansion of single-family homes into the open areas.

In their description of existing conditions, these documents portray the lifestyle and architecturally unique housing as low-quality and mildly primitive. This is particularly true for the northern portion of Trnovo, were individuals lived in the architecturally unique, historic "gardeners' houses" and worked adjacent plots of land. The 1970 Technical Section of the Construction Plan notes that The age of the housing stock, of some commercial-industrial jerry-rigged buildings, and of their furnishings guarantees only minimum conditions for living and work to residents [LUZ 1970: 19]. The area in the southern part of Trnovo was understood differently, however, as noted in the slightly later 1972 Program Section of the Construction Plan: The southern portion, which in great measure has newer and better preserved housing - largely individual [family] housing - will in general be preserved [LUZ 1972: 7]. 
Figure 4: Trnovo historic housing [Photo: J. Fikfak, 2005].

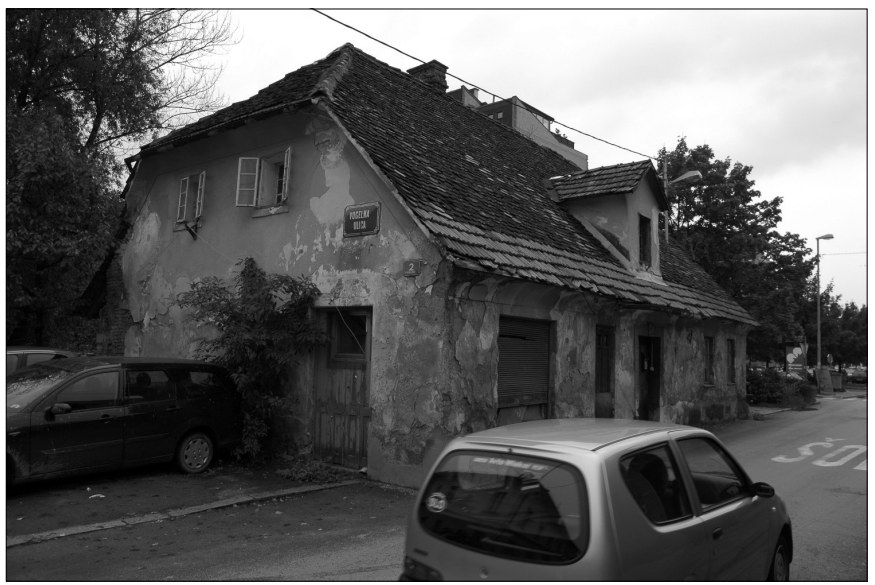

In listing the positive aspects of the neighborhood, the 1970 Program Section of the Construction Plan underscores the potentially modernizable characteristics of the area as its best assets - these being its location and potential to accommodate (new) high-quality housing. These features were all to be incorporated into the new plan, which was to emphasize "modern" living in high-rise apartments and extensive individual housing. Thus, the declared criteria determining favorability in housing was newness, or modernist-ness, couched in questions of quality of life. Undeclared in this vision of the modern neighborhood was the clear consequence of this plan: all the historic housing and adjoining gardens, associated with "folksy" Trnovo since at least the 1933 popular ethnographic study, would be physically erased.

However, these plans also contain an unexpected, passing nod of reverence for prewar, early modern architecture, as well as prewar popular conceptions of Trnovo. In its program section, the 1970 Technical Section of the Construction Plan notes:

In addition, we wish to respect in full measure the significant qualities of the wider region and the area per se: its limited distance from the city center, the environment of the Ljubljanica and Gradašcica Rivers, the striking views of the Ljubljana Castle, Krim Mountain, and the Trnovo church.... Trnovo definitely has certain fundamental advantages over other locations of such size in Ljubljana... One quality advantage of the neighborhood is certainly its oft-emphasized proximity to the city center, which with the new extension of Titova Cesta will be brought even closer to the neighborhood, to under one thousand meters away.... The Gradašcica River on one side, and the Ljubljanica River on the other, together with the church and Plecnik's museum create natural boundaries for this already peaceful area, which, given the low quality of the existing housing, does not impart to Ljubljana any particularly characteristic image, except insofar as it is underscored by 
Plečnik's development of the Gradaścica River, and perhaps by the little vegetables gardens. [LUZ 1970: 5, 18-19]

By acknowledging Jože Plečnik's masterful riverfronts and the baroque church and buildings around them, the Construction Plan makes an unexpected acknowledgement of the legacy of the early modern architect that settled behind the riverfronts Plečnik designed and the baroque Trnovo church whose plaza he created - and which his faithful attendance of led to his being professionally ostracized after the Second World War, although he had established the profession of architecture in Slovenia in the 1920s [Prelovšek 1997; Krečič 1993]. In addition, this document contains a similar nod to the "little vegetable gardens," so greatly beloved in all other narratives on the neighborhood. Perhaps this passing acknowledgement was intended to explain why a minute area of historic gardens was preserved in the plan, as well as Plečnik's urban designs, although these two physical features speak in direct opposition to the narrative on modernity espoused by the urban planners and, instead, align directly with the vision of modernity voiced by the plan's opponents.

\section{PROMINENT INDIVIDUALS’ NARRATIVES ON THE PLAN}

Of those opposed to the plan, socially prominent individuals expressed a multivocal set of beliefs on what would constitute an acceptably modern design for Trnovo, grounding their sense of modernity either in a Romantic vision of the "folk" or in a reverence for Plečnik's stunning early modern architecture. As the voices of individuals that successfully negotiated socially prominent positions for themselves under socialism - such as television commentator, art historian, museum director, and university professor - these narratives are interesting for their political multivocality. In addition, this is the group of individuals that were able to affect change to the neighborhood plan, through discussions within informal professional networks that are not discussed in this article. When interviewed, these individuals that were highly visible during the socialist period note the need for modernization of Trnovo's housing stock, but ground their vision of an acceptable "modern" Trnovo in a negotiated modernity constituted by pre-socialist and socialist-era beliefs.

One such individual is the well-known Jože Hudeček, ${ }^{3}$ a popular and regular television commentator betwen the 1960s and 1990s. Today retired and a novelist, Hudeček has written extensively on Trnovo, where he spent time as a small boy, and is a good representative

3 Following standard U.S. ethnographic practice and because all conclusions are my own, I use pseudonyms for all my field consultants in this text, although they all gave me permissions to cite them by name. I make an exception for those consultants that are so well known to the Slovenian public that they would be recognized immediately by local readers. Because Jože Hudeček is one such very well known public figure, I use his true name in this text, but I refer to my two Trnovo field consultants by pseudonyms that I created for them. 


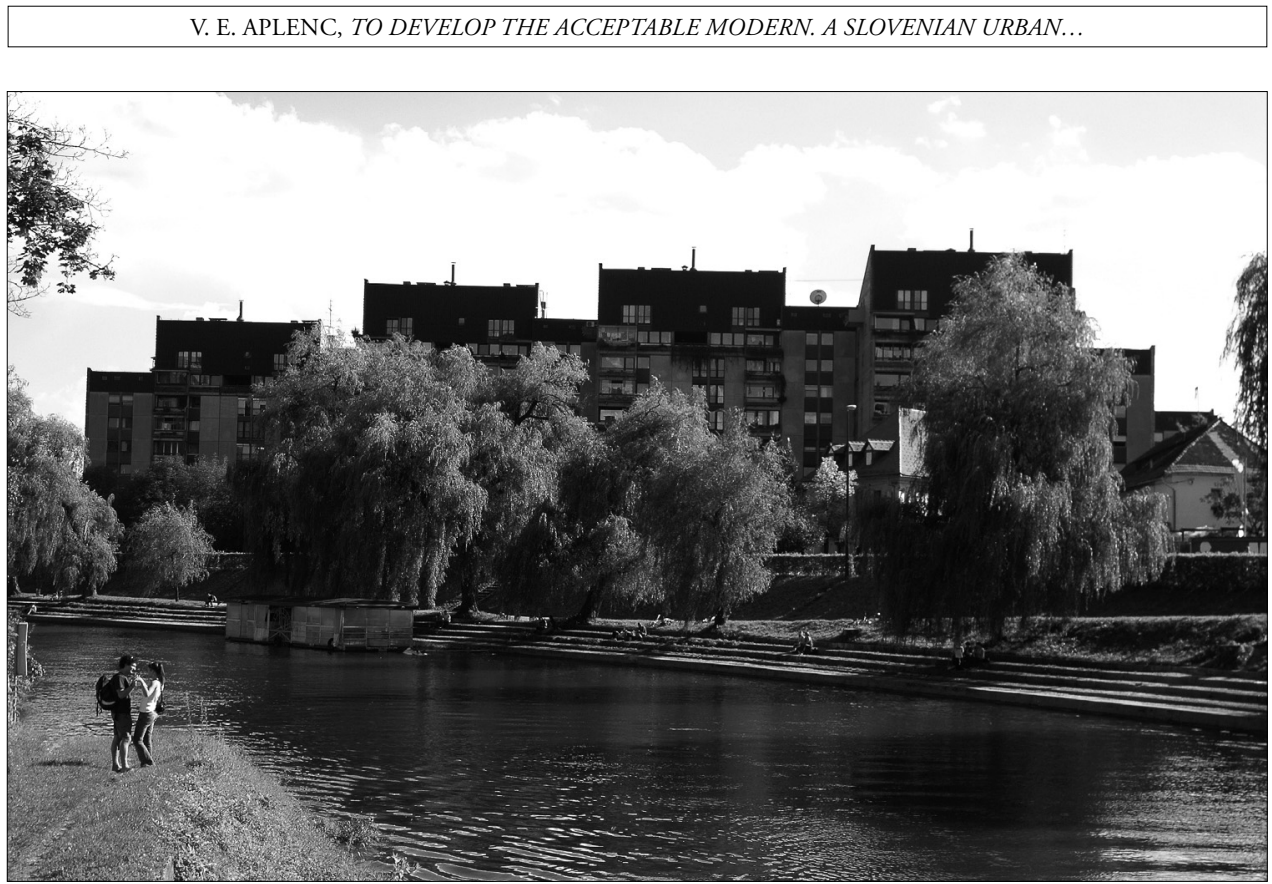

Figure 5: Jože Plečnik’s Ljubljanica River riverfronts [Photo: J. Fikfak, 2005].

of the narratives on Trnovo frequently expressed by the socially prominent. Interestingly, in 2001-2002 he was recommended by everyone as the living authority on Trnovo - although he only lived there as a child and is from a local gardening family of "old Trnovo residents." Hudeček remembers Trnovo as a refuge from the Second World War, and his descriptions of this neighborhood have a romantic tone that is reminiscent of early 20thcentury ethnology:

Well - ah, this Trnovo, you know, this was the Trnovo of one-story houses ... because at every hour of the day, because they devoted their entire life, these farmers, actually, or, these near-city dwellers, every hour they went to their garden and watered what needed watering, they put down a covering if a storm or hail was threatening, they covered the lettuce so that the hail wouldn't destroy it, so on and so forth, in short, by these products, which were truly excellent, the people of Trnovo stood watch day and night. They were there so that they could serve the land and its products. Carnations grew there, roses also grew there, whose gardens were actually a kind of heaven on earth, with which the people of Trnovo were in love.

Hudeček portrays a very "19th-century-folk"-like picture of the Trnovo locals, as people completely dedicated to their farming way of life, and yet somehow also able to produce nationally significant sons, such as artists and engineers. Hudeček is quick to contrast this "traditional" way of life with the American one - which, to his eyes, lacks belonging (identity), sense of place, and sense of history. When pressed on the history of Trnovo's de- 


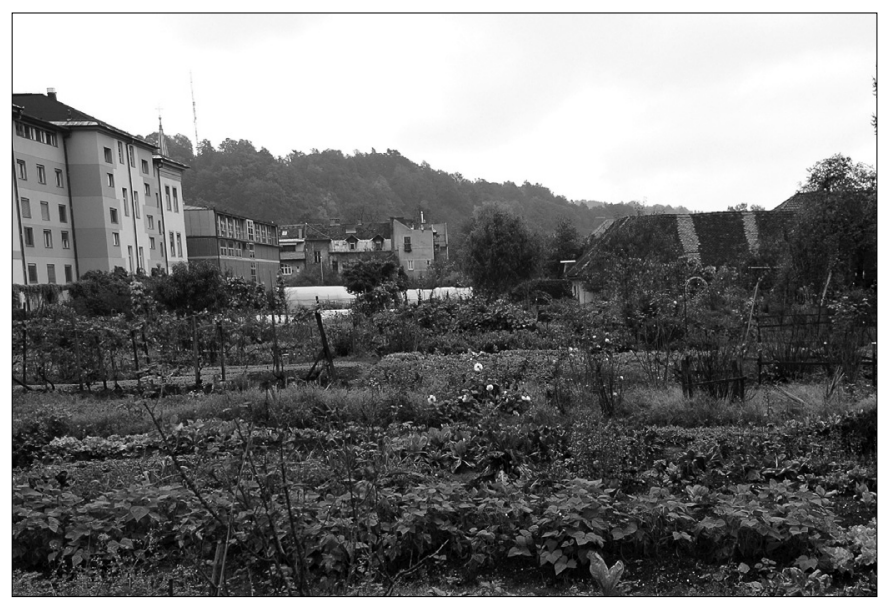

Figure 6: Krakovo gardens

[Photo: J. Fikfak, 2005].

velopment, however, Hudeček concedes the need for the modernization of historic Trnovo, noting ...those earlier, single-story, little houses which had, say, uninsulated foundations, where people lived out their days in an unhealthy environment - it was damp, for example. Hudeček, however, has no love lost for the new settlement that replaced the neighborhood of his childhood. When speaking of Trnovo, he frequently notes the suicides and disorientation that followed the displacement of - for him - its special population, in an indirect critique of the "necessity" of this development:

A whole generation, essentially, or even two generations, fell into ruin, went to their deaths, because it was necessary, in the place of those little, damp, but above all friendly little houses, which were a part of man, it was necessary to build there [cough] gigantic, sleeping-quarter [shipping] containers, ah, in which people no longer "head home," but "head to sleep."

In his vision of an appropriate Trnovo, Hudeček references the romantic, "folksy" way of life that the state-produced documents make a passing nod to, but primarily intend to eradicate and that, although not discussed here, figured as a powerful political thorn in both Slovenian and Yugoslav communist discourse. For Hudeček, this "folksy" population is not the nemesis of modernity, but is rather an integral element to his conception of himself as modern, with the "folksy" Trnovo residents as traditional, historic and pre-modern at best. With this stance, Hudeček unknowingly echoes Slovenian professional ethnological conceptions of the "folk" foundation of the nation, which enjoyed a continuity from the early 20th-century inception of the profession through the socialist era [ETSEO 1976; Kremenšek and Bogataj 1980; Kremenšek 1989; Kumer 1973; Matičetov 1948; Kuret 1972; Muršič and Ramšak 1995; Stanonik 1989; Terseglav 1990]. In fact, Hudeček opposes his "folk"-based modernity to the past-less, place-less modernity that is created by gigantic, dormitory [shipping] containers that the socialist urban planners hoped would create an ideal, modern urban environment. For Hudeček, the "folksy," old Trnovo should be have been preserved as the roots on which modern society could stand - a belief very much shared 
by pan-Western narratives on the nation-state [Handler 1988] and on heritage [Karp and Lavine 1991; Karp, Kreamer, and Lavine, 1992].

\section{LOCAL NARRATIVES ON THE PLAN}

Local Trnovo residents echo Hudeček's disapproval of the destruction of old Trnovo but, in contrast to Hudeček, do not see themselves as "folksy," pre-modern, or as the object of the plan's destructive intentions. Like Hudeček, long-time Trnovo residents from gardening families lament the loss of old Trnovo, but in contrast their narratives underscore their loss of a way of life and the destruction of a beautiful environment.

Matej Polanec, a 70-year farmer explains, They built up everything on us, right, built up everything. They made high-rise buildings here, they destroyed the old Trnovo. Which I am very sorry about. His feelings are echoed by Renata Koželj, now in her late 40s and whose mother continues to garden commercially:

$R K$ : And then, when we, ah, when they began - I mean, which this construction, I mean, they destroyed Trnovo that way.

$V A$ : Do you think so?

RK: For sure. They did.

$V A$ : What did-

RK: I mean, that, ah, ah, feeling, when you cam here, from, the Trnovo church, and then, over there, where [the neighborhood] Trnovo begins, right? Right over that little bridge, right? It was - the end. Now, you look at high-rises, right? Before you came over that little Karunova Ulica, and there were gardens on the left and right. I mean. It was, it was something you could feel. You know. [short pause] But now, ah, -.

Although Trnovo locals clearly condemn the results of the urban plan, they view their loss as one of a former way of life, and not of a "folksy" environment of which they were a part. In fact, they locate the "folksy" elsewhere, specifically, in what are for them true farming communities. Thus, these local residents, professional gardeners or farmers, clearly define themselves as modern, versus the "true folk." Local farmer Matej Polanec clarifies why Trnovo is not a community of peasants or the "folk":

MP: You know, [the old residents of Trnovo] they were the kind of people who had a farm, but, ah, they weren't really farmers. They had something else besides that, they were employed somewhere else. The wife worked in the garden ... the husband went to work, say, there, or he was, say, here, [employed] on the tramway, or - whatever, right?... The Trnovo women went to the market, right? Um, with those carts... But they weren't really farmers....

VA: And who are really farmers? In what -? 
MP: Those who only live from the land.... They don't go to work, they don't have a job, right?... [The Trnovo women] were housewives, at home, and they went to the market [to sell their produce], and they worked the garden, right?

In making this important distinction, Polanec is clarifying the meaning of the Slovenian word kmet 'farmer, peasant' and it is this term that is used for the Herderian, mythic originators of the nation. The adjective kmečki 'of the peasantry, peasant' is a term that is regularly used by non-local residents to describe Trnovo, although the neighborhood has contained very little of anything "peasant" since the 1700s. Polanec's distinction resonates with the dictionary definitions of kmet 'farmer, peasant' and kmetovanje 'farming', versus vrtičkarstvo 'small-scale gardening for commercial profit or pleasure'. According to this

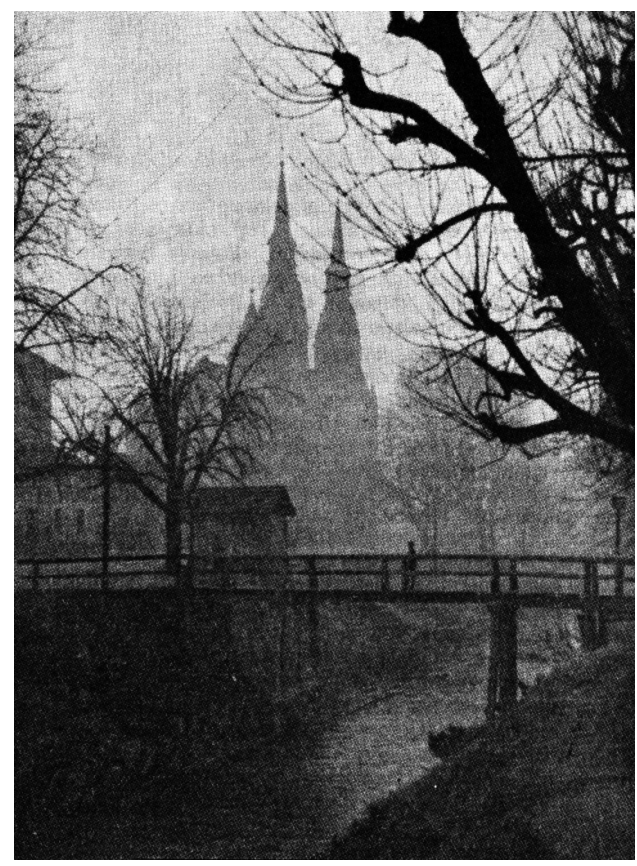

Figure 7: Historic Trnovo [Vrhovnik 1933: 11]. differentiation, none of the historically renowned Trnovo "folk" figures are peasants or farmers - neither the stereotypical Trnovo branjevka 'reseller of produce' or the solatarica 'lettuce-lady' that grows and sells products such as the well-known ljubljanska ledenka 'Ljubljana iceberg lettuce'. This distinction accounts for Trnovo's being classified by Slovenian ethnologists as semi-rural or semi-village, and not kmečki 'rural' [Bogataj 2002] and aligns with historical facts [Turistično društvo Trnovo 1991; Otorepec Tercelj 2001; Valvasor 1689; Vrhovnik 1933]. Thus, local Trnovo residents ground their vision of modernity in a personal link with an environment, a vision that resembles Hudeček's narrative on the "folk" but fundamentally contrasts with it in the location of the Other.

\section{CONCLUSION}

Despite protests in the media and in professional circles, the plan for Trnovo was fully realized by the late 1980s. Opposing voices that wished to protect the old Trnovo were somewhat successful in mitigating the plan, although these negotiations were made through informal professional networks and are rumored to have resulted in the loss of at least one career. Although these physical changes to Trnovo were very real, narratives on the plan and on the neighborhood reveal clashing conceptions of the "folk" that complicate what 
Figure 8: Trnovo's mixed landscape [Photo: J. Fikfak, 2005].

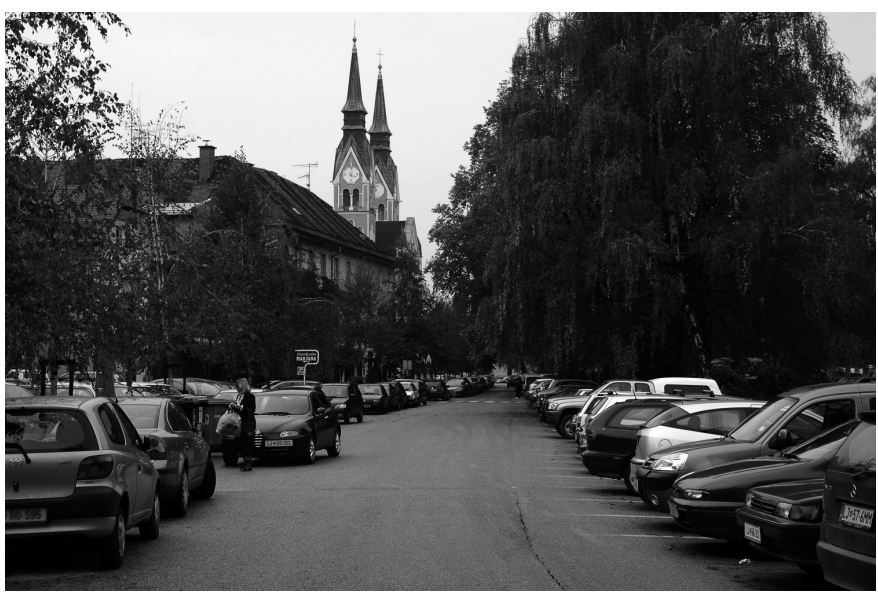

otherwise appears to be a simple story of neighborhood destruction by outside forces of modernization. In the official gaze of 1960s urban planners, Trnovo held almost nothing modern, a shortcoming that needed to be professionally corrected. To the sensibilities of successful, prominent, and well-educated individuals in socialist society, Trnovo held very little of the modern - and this precisely was what made it significant for Ljubljana, within Slovenia. However, in the eyes of the Trnovo residents whose families had engaged in commercial gardening for several generations, they and Trnovo had always been part of the modern. The landscape that resulted from the implementation of the 1960s plans mirrors these disparate notions of modernity: old farmhouses, high-rises, and a vast and startling socialist suburbia sit next to one another, but do not mingle.

\section{REFERENCES}

Bogataj, Janez

2002 Interview by author. Ljubljana, Slovenia, 28 June 2002.

Etnološka topografija slovenskega etničnega ozemlja [ETSEO]

1976 Vprašalnice 5 (Questionnaire 5). Ljubljana: Raziskovalna skupnost slovenskih etnologov.

Handler, Richard

1988 Nationalism and the Politics of Culture in Quebec. Madison, WI: University of Wisconsin Press.

Karp, Ivan, and Steven D. Lavine

1991 (eds.) Exhibiting Cultures. The Poetics and Politics of Museum Display. Washington, DC; Smithsonian Institution Press. 
Karp, Ivan, Christine Mullen Kreamer, and Steven D. Lavine

1992 (eds.) Museums and Communities. The Politics of Public Culture. Washington, DC: Smithsonian Institution Press.

Krečič, Peter

1993 Plečnik. The Complete Works. New York, NY: Whitney Library of Design.

Kremenšek, Slavko

1989 Ob jubileju univerzitetnega profesorja dr. Vilka Novaka (Celebrating University Professor Vilko Novak). Traditiones 18: 55.

Kremenšek, Slavko, and Janez Bogataj

1980 (eds.) Poglavja iz metodike etnološkega raziskovanja - 1 (Chapters in the Methodology of Ethnological Research 1). Ljubljana: Filozofska Fakulteta Univerze Edvarda Kardelja v Ljubljani.

Kumer, Zmaga

1973 (ed.) Zbornik 18. Kongresa jugoslavanskih folkloristov (Proceedings of the 18th Congress of Yugoslav Folklorists). Ljubljana: Slovensko etnografsko društvo.

Kuret, Niko

1972 75-letnica prvega slovenskega narodopisnega programa (75th Anniversary of the First Slovenian Ethnographic Project). Traditiones 1: 19-26.

Matičetov, Milko

1948 O etnografiji in folklori zapadnih Slovencev (On the Ethnography and Folklore of the Western Slovenians). Slovenski etnograf 1: 9-56.

Mihelič, Breda

1983 Urbanistični razvoj Ljubljane (The Urban Development of Ljubljana). Ljubljana: Znanstveni inštitut Filozofske fakultete v Ljubljani and TOZD.

Mlinar, Zdravko

1978 Urbanizacija, urbanizem in sociologija (Urbanization, Urban Planning, and Sociology). Ljubljana: Univerza v Ljubljani, Fakulteta za sociologijo, politične vede in novinarstvo.

1983 Humanizacija mesta. Sociološke razsežnosti urbanizma in samoupravljanja v Novi Gorici (The Humanization of the City. Sociological Dimensions of Urban Planning and Self Management). Maribor: Obzorja.

Muršič, Rajko, and Mojca Ramšak

1995 Razvoj slovenske etnologije od Štreklja in Murka do sodobnih etnoloških prizadevanj. Zbornik prispevkov s kongresa Ljubljana, Cankarjev dom, 24. - 27. oktobra 1995 (The Development of Slovenian Ethnology from Strekelj and Murko to Modern Ethnological Efforts. Proceedings from the Ljubljana Congress, Cankarjev Dom, 24-27 October 1995). Ljubljana: Slovensko etnološko društvo (Knjižnica Glasnika Slovenskega etnološkega društva; 23). 
Mušič, Vladimir

1980 Urbanizem - bajke in resničnost: zapisi na robu dvajsetletnega razvoja našega prostorkega načrtovanja (Urban Planning: Legends and Truth. Marginal Notes on 20-Years of Development of Spatial Planning). Ljubljana: Cankarjeva založba.

Otorepec Tercelj, Mojca

2001 Trnovski tičarji in solatarce (Trnovo Poultry Breeders and Lettuce Ladies). Ljubljana: Prešernova družba.

Pogačnik, Andrej

1980 Urbanistično planiranje. Učbenik (Urban Planning: A Textbook). Ljubljana: Tiskovna komisija VTOZD Gradbeništvo in geodezija Fakultete za arhitekturo, gradbeništvo in geodezijo Univerze Edvarda Kardelja.

Prelovšek, Damijan

1997 Jože Plečnik, 1872-1957. Architectura Perennis. Transl. from the German edition (Salzburg, 1992) by Patricia Crampton and Eileen Martin. New Haven, CT: Yale University Press.

Stanonik, Marija

1989 Slovenska različica primerjalne slovstvene folkloristike: Oris raziskovalnega dela dr. Milka Matičetova (The Slovenian Version of Comparative Literary Folklore: An Outline of Research by Milko Matičetov). Traditiones 18: 7-54.

Terseglav, Marko

1990 Ustno slovstvo in folkloristika kot predmeta univerzitetnega študija (Oral Literature and Folklore Studies as an Object of University Study). Traditiones 19: 233-260.

Turistično društvo Trnovo

1991 Trnovo in Krakovo (Trnovo and Krakovo). Ljubljana: Turistično društvo Trnovo.

Valvasor, Johann Weichard

1689 Die Ehre deß Herzogthums Crain (The Glory of the Duchy of Carniola). Nuremberg: Wolfgang Moritz Endter.

Vrhovnik, Ivan

1933 [1991] Trnovska župnija v Ljubljani (The Parish of Trnovo in Ljubljana). Facsimile of 1933 edition, issued for the centenary of the arrival of Ivan Vrhovnik in Trnovo. Ljubljana: Akademska založba.

\section{Maps and Plans}

Ljubljanski urbanistični zavod [LUZ]

1966 Generalni Plan Urbanističnega Razvoja Ljubljane (General Plan for the Urban Development of Ljubljana). Ljubljana: Ljubljanski urbanistični zavod.

1970 Tehnični del zazidalnega načrta VS1 in VS102 - Trnovo (Technical Section of the 
Construction Plan for VS1 and VS102 - Trnovo). Ljubljana: Ljubljanski urbanistični zavod.

1972 Zazidalni načrt VS1 in VS102 - Trnovo: programski del (Construction Plan for VS1 and VS102 - Trnovo: Program Section). Ljubljana: Ljubljanski urbanistični zavod.

1983 Dopolnitev zazidalnga načrta za severni del VS1 - Trnovo (Supplement to the Construction Plan for the Northern Part of VS1 - Trnovo). Ljubljana: Ljubljanski urbanistični zavod.

1988 Dokumentacija za realizacijo zazidalne zasnove za del območja urejanja VS 2/2 (Trnovo) - Eipprova ulica (Documentation for Carrying Out the Construction Project for the Section of the Area Covered by VS 2/2 (Trnovo) - Eipprova Ulica). Ljubljana: ZIL, TOZD URBANIZEM - LUZ Ljubljanski urbanistični zavod.

\section{KAKO RAZVITI SPREJEMLJIVO MODERNO. SLOVENSKA URBANA KRAJINA V SOCIALIZMU, 1969-1982}

Soseska Trnovo v Ljubljani je dolga leta slovela kot "preprost "vrtnarski predel mesta, ki leži tik zunaj starega srednjeveškega mestnega jedra. Med 17. in začetkom 19. stoletja se je Trnovo razvilo $v$ živahen trgovski podaljšek mesta, ki je Ljubljano oskrboval sključnimi uslužnostnimi dejavnostmi, vključno z doma pridelanimi poljščinami za prodajo mestnim prebivalcem. Čeprav je bilo sredi 19. stoletja Trnovo priključeno širšemu območju Ljubljane, je obdržalo svoje prvotno vaško ozračje tudi še potem, ko so po načrtih mednarodno uveljavljenega slovenskega arhitekta Jožefa Plečnika v 30. letih 20. stoletja na tem območju preoblikovali rečne bregove in postavili mostove.

Med letoma 1969 in 1982 so od države nastavljeni urbanisti zasnovali urbanistični načrt za sosesko Trnovo v Ljubljani, ki je bila tedaj še del Jugoslavije. Načrt je zahteval, da se zgodoviski del soseske porusi, na njegovo mesto pa postavi stolpnice in socialistično oblikovano predmestje. Nasilni urbanistični načrti stanovanjskih sosesk, ki so bili delo državnih uradnikov, za socialistično družbo niso nič presenetljivega. V primeru Trnovega je prvotni urbanistični načrt iz leta 1969, ki ga je izdelala državna uprava, trčil na silovit odpor. Po desetletju izmenjave mnenj in kompromisov med strokovnjaki je bila na podlagi nekoliko spremenjenega načrta soseska končno dograjena leta 1982. Urbana krajina, ki se je na koncu rodila, je bila fizično zelo raznolika: stare kmetije so bile razkropljena med stolpnicami in po rastočem socialističnem predmestju. Odsevala je nasprotujoča si mnenja o Trnovem in o tem, kaj je sodobno. Uradni urbanisti, ugledni strokovnjaki in pa sami prebivalci Trnovega so imeli sebe in svojo vizijo Trnovega za sodobne, vendar so svoje poglede izoblikovali na osnovi izključujočih si definicij o tem, kdo so tisti drugi, preprosti ljudje.

Uničenje Trnovega jasno kaže na želje države, da bi izbrisala nezaželeni element in ga oblikovala na novo, v skladu socialističnimi načeli. Prva serija urbanističnih načrtov, ki so nastali leta 1969 in bili potrjeni leta 1972, je odsevala sodobne urbanistične težnje, da bi oblikovali nova urbana okolja, v katerih bi socialistični državljani lahko razvili vse svoje potenciale. Zlasti 
pa so se ti načrti ujemali z uradno zapovedano jugoslovansko urbanistično vizijo, po kateri bi bilo treba odstraniti razlike med urbanimi in vaškimi četrtmi. Prav nič presenetlivo ni, da je bilo za to izbrano prav Trnovo, saj je veljalo za dobro poznano, skoraj vaško območje v ožjem ljubljanskem središču; njegovo "ljudskost" sta dokumentirali tudi deli etnografov iz let 1689 (Valvasor) in 1933 (Vrhovnik).

Državna socialistična vizija, kaj je na področju urbanega planiranja moderno, je jasno razvidna $v$ prvi seriji urbanističnih načrtov za Trnovo, nastalih v letih 1969-1972. Po teh načrtih bi bilo treba porušiti vse območje "starega" Trnovega in tako ustvariti prostor za stolpnice in za nove enodružinskih hiše. V opisih stanja dokumenti navajajo takratni način življenja in izjemno arhitekturno podobo tega stanovanjskega predela kot nekoliko primitivno četrt slabe kakovosti. Takratna prednostna merila $v$ arhitekturi so poudarjala novo in moderno, oboje pod plaščem kakovosti življenja. Vendar pa urbanistični načrti za Trnovo vsebujejo tudi rablo zaznavno in nepričakovano spoštovanje tako do predvojne, zgodnje moderne arhitekture kakor do predvojnega ljudskega razumevanja Trnovega.

Nekateri družbeno pomembni posamezniki, ki so načrtom nasprotovali, so navajali različna si mnenja, kaj bi po njihovem sodilo v še dopusten, sodoben načrt Trnovega, svoje pojmovanje sodobnega pa so utemeljevali bodisi na nekakšni romantični viziji "ljudskega" ali pa na občudovanju izredne zgodnjemoderne Plećnikove arhitekture. Iz pripovedih teh posameznikov, ki so $v$ času socializma dosegli ugledne družbene položaje - med njimi npr. televizijski komentator, umetnostni zgodovinar, direktor muzeja in univerzitetni profesor - je razvidno, da so njihova mnenja zelo zanimiva zaradi političnega večglasja. Poleg tega je bila to skupina posameznikov, ki se ji je posrečilo doseči spremembo urbanističnih načrtov za Trnovo s pomočjo neformalnih pogovorov v svojem poklicnem okolju; vendar to ni predmet tega članka.

$V$ intervjujih so omenjali potrebo po modernizaciji trnovskega stanovanjskega dela, vendar pa so svoje razumevanje še dopustno "modernega" Trnovega oprli na končno dosežen kompromis med elementi iz predsocialističnega in socialističnega časa. Za te posameznike "preprosto" prebivalstvo ni nekaj, kar bi oviralo modernost, temveč nekakšen integralen element njihovega lastnega pojmovanja modernosti, medtem ko velja, da so "preprosti "Trnovčani "tradicionalni", "zgodovinski«, in v najboljsem primeru pred-moderni.

Prebivalci Trnovega sicer soglašajo z mnenjem družbeno uveljavljenih posameznikov, da je bila četrt uničena, vendar pa se v nasprotju z njimi ne dojemajo kot "preprosti ", predmoderni, ali pa kot tarče uničevalnih namenov urbanističnih načrtov. Tisti krajani, ki v tej četrti živijo že dolgo in ki izhajajo iz družin, ki so se preživljale s prodajo vrtnin, sicer objokujejo izginotje starega Trnovega, vendar pa za razloček od omenjenih strokovnjakov poudarjajo zgubo svojega prejšnjega načina življenja in uničenje lepega okolja. Čeprav zelo jasno obsojajo nastale rezultate urbanističnega načrta, svojo zgubo dojemajo kot zgubo življenjskega stila, ne pa "preprostega" okolja, katerega del so bili. "Preprostost " pripisujejo drugemu okolju, območjem, ki jih imajo za pristno kmečke in ki ležijo drugje, zunaj Trnovega. Ti krajani, poklicni vrtnarji in kmetje, se očitno imajo za moderne, za drugačne od "resnično preprostih ljudi." Očitno je, da Trnovčani pojmujejo modernost v osebni povezavi z okoljem, $v$ čemer se sicer strinjajo s pojmovanjem "ljud- 
skega, preprostega", ki so ga navedli družbeno uveljavljeni posamezniki, vendar pa se njihovo pojmovanje tega, kje je moč najti one druge, preproste ljudi, bistveno razlikuje od prvega.

Čeprav so bile nastale spremembe $v$ Trnovem zelo otipljive, pa pripovedi o urbanističnih načrtih in soseski, ki bi bila drugače videti kot preprosta zgodba o soseski, ki so jo uničile sile modernizacije, odkrivajo nasprotujoče si koncepte "ljudskega, preprostega". Po mnenju uradnih urbanistov v 60. letih 20. stoletja $v$ Trnovem ni bilo skoraj nič modernega, to pomankljivost pa je bilo treba strokovno odpraviti. Za uspešne, pomembne in visoko izobražene posameznike socialističnega obdobja je Trnovo vsebovalo le malo modernih elementov, prav to pa je bila po njihovem pomembna prednost za Ljubljano. Nasprotno pa so imeli prebivalci Trnovega, katerih družine so se že nekaj generacij ukvarjale s prodajo pridelkov s svojih vrtov, sebe in svojo sosesko od nekdaj za sodobno. Krajina, ki so jo končno zgradili po načrtih iz šestdesetih let, lepo odseva te povsem različne poglede na sodobnost. Stare kmetije, stolpnice in razsežno socialistično predmestje tako stojijo drug ob drugem, pa vendar vsak zase.

Dr. Veronica E. Aplenc

University of Pennsylvania, 303 Logan Hall/6304 Philadelphia, PA 19104, USA vaplenc@sas.upenn.edu 